\title{
IgM-class rheumatoid factor interference in the solid-phase radioimmunoassay of rubella-specific . IgM antibodies
}

\author{
O. H. MEURMAN AND B. R. ZIOLA \\ From the Department of Virology, University of Turku SF-20520 Turku 52, Finland
}

SUMMARY The interference of IgM-class rheumatoid factor (RF) in the solid-phase radioimmunoassay (RIA) of rubella virus IgM antibodies was studied. Acute rubella infections did not significantly activate RF. False-positive rubella antibody results were obtained, however, when patients with raised RF levels were tested. If a low rubella IgG antibody titre was present, a high level of RF was required to cause a false-positive IgM result; conversely, in sera with high IgG titres, only a low level of RF was required for interference. Although the false-positive IgM titres obtained were generally low, they did show a positive correlation to both RF levels and rubella IgG titres. False-positive results were successfully avoided by removing the RF by absorption with heat-aggregated human gamma globulin. The absorption procedure did not affect true rubella IgM antibody titres.

In modern virology and microbiology, human antibodies are, to an increasing degree, detected by immunoassays using marked anti-human immunoglobulins. An indirect fluorescent antibody technique (IFAT), an immunoperoxidase technique, an enzyme-linked immunosorbent assay, and a radioimmunoassay (RIA) have all been used in rubella serology (Haire and Hadden, 1970; Voller and Bidwell, 1975; Gerna and Chambers, 1976; Kalimo et al., 1976). A great advantage of these assays is the possibility of obtaining a rapid diagnosis of a recent infection by demonstrating specific IgM-class antibodies. However, in all assays which detect IgM antibodies by anti-human-IgM immunoglobulins, IgM-class rheumatoid factor (RF) is potentially capable of causing a false-positive IgM result, as has been clearly demonstrated in the case of the IFAT by Shirodaria et al. (1973).

Preliminary work indicated that the solid-phase RIA method developed in our laboratory for detection of IgM antibodies against rubella virus (Kalimo et al., 1976; Meurman et al., 1977) is affected less by the presence of the RF than is the IFAT. More detailed studies on the effect of RF in

Received for publication 7 December 1977 our IgM antibody RIA, however, required an equally sensitive method for determination of RF; therefore, a solid-phase RIA for IgM-RF was developed (Ziola et al., in press). Further investigations on the interference of RF in the solid-phase rubella IgM RIA were then undertaken. The results obtained are presented in this report.

\section{Material and methods}

\section{SERUM SPECIMENS}

A total of 199 serum specimens were tested. These included 126 serial specimens from 28 patients with an acute rubella virus infection, 61 single serum specimens from patients with rheumatoid arthritis, and 10 single serum specimens from other patients having raised RF levels. In addition, two control specimens with low RF levels were used, one being negative for both rubella-specific IgG and IgM, and the other having a high rubella IgG antibody titre but no rubella IgM antibodies.

RUBELLA IgG AND IgM ANTIBODY RIA The Therien strain of rubella virus (originally received from Dr Schluederberg, Yale University) was grown in roller cultures of VERO cells (Liebhaber et al., 1969). Eagles basal medium (BME) containing 0.2\% bovine serum albumin (fraction V), 5\% tryptose phosphate broth, and antibiotics was used as main483 
tenance medium. After four to five days, when haemagglutinin was demonstrable in the maintenance medium, the medium was harvested and replaced with fresh medium. Daily harvests were continued until the cells showed advanced degeneration, usually by about one week. The collected media were pooled, clarified by low-speed centrifugation, and concentrated 10 - to 40 -fold by ultrafiltration in a Bio-Fiber 80 Beaker (Bio-Rad Laboratories, Richmond, Calif, USA). The virus antigen was then purified by pelleting through $15 \%$ sucrose onto a cushion of $60 \%$ sucrose (Kalimo et al., 1976) after which the sucrose was removed by dialysis.

The RIA procedure described previously (Kalimo et al., 1976; Meurman et al., 1977) was used with the following modifications: phosphate buffered saline containing $0.5 \%$ bovine serum albumin and $0.5 \%$ Tween $\mathbf{2 0}$ was used as the serum diluent, and Eagles minimum essential medium containing $10 \%$ heatinactivated calf serum, $0.5 \%$ lactalbumin hydrolysate, $0.1 \% \mathrm{NaN}_{3}$, and $1 \%$ Tween 20 was used as diluent for the labelled anti-human-immunoglobulins. Briefly, rubella virus antigen was adsorbed onto polystyrene balls (Precision Plastic Ball Co, Chicago, Ill, USA) at a concentration of $5 \mu \mathrm{g}$ protein/ball, and serum antibodies binding to the antigen were detected by ${ }^{125}$ I-labelled anti-humangamma and anti-human-mu immunoglobulins. The anti-human-gamma and -mu immunoglobulins were isolated by immunoabsorbent column chromatography from sera obtained from Orion Diagnostica (Helsinki, Finland). The isolated homogeneous antibodies were labelled with 125I (Amersham, England) as detailed elsewhere (Ziola et al., 1977). The specificity of the iodinated indicator molecules was checked by using in the actual RIA procedure IgM and IgG fractions isolated from a rubella positive serum.

RHEUMATOID FACTOR RIA

The assay, which is based on the principle of RF binding to natural antigen-antibody complexes, can be used to determine RF levels which are undetectable by the latex or Waaler-Rose agglutination tests (Ziola et al., in press). Briefly, respiratory syncytial virus (RSV) infected VERo cell lysate antigen was adsorbed onto polystyrene balls by submerging the balls overnight at room temperature in an antigen solution containing $7 \mu \mathrm{g}$ protein/ball. The balls were then dried and incubated overnight at room temperature in a solution containing $4 \mu \mathrm{g} /$ ball of IgG isolated from a serum pool of convalescent patients. The RSV antigen-coated balls with immunologically bound IgG were then dried and used in the RF RIA; excess balls were stored in the antibody solution at $4^{\circ} \mathrm{C}$ until required. A lysate of RSV infected cells was chosen as the antigen for the assay since virtually all of the virus antigen remains cell-associated, and large quantities can easily be produced. Such a $\overrightarrow{\vec{F}}$ membrane-associated antigen was found to be ideal for the coating of the polystyrene balls.

Serum specimens were tested at a dilution of $1: 200$, $\frac{\overline{\bar{c}}}{\bar{c}}$ and binding of RF to the IgG in the immune com- $\bar{\Phi}$ plexes on the solid-phase was detected by $125 \mathrm{I}-\mathrm{O}$ labelled anti-human-mu indicator antibodies. The $\mathrm{ct} / \mathrm{min}$ data obtained for each serum were converted $\overrightarrow{0}$ to units by comparison with a standard curve $\vec{\overrightarrow{ }}$ obtained by assaying dilutions of a reference RF $\tilde{\sigma}$ serum pool to which had been assigned an arbitrary value of 1000 units. Normal human sera were found $\dot{\omega}$ to contain between 5 and 20 units of RF (values $\vec{c}$ being rounded to the nearest integral divisible by five). The amount of RSV convalescent IgG used per $\underset{\omega}{\infty}$ antigen-coated ball was sufficient to saturate the 0 antibody binding sites of the solid-phase RSV antigen. Analysis of serum specimens from 24 early $\vec{z}$ convalescent RSV patients found RF levels of 5 to 30 units, with a mean of 11.9 units. This was not $\vec{\theta}$ significantly different from the RF levels of normal human sera or rubella convalescent sera (see Results).

REMOVAL OF RHEUMATOID FACTOR

A modification of the method described by Shirodaria et al. (1973) was used. Human gamma 응 globulin $(160 \mathrm{mg} / \mathrm{ml})$ was aggregated by heating at $\stackrel{\mathbb{Q}}{\varrho}$ $73^{\circ} \mathrm{C}$ for 10 minutes. One hundred microlitres of the $\overrightarrow{\overline{0}}$ test serum were incubated with $300 \mu$ l aggregated $\frac{0}{3}$ gamma globulin for one hour at $37^{\circ} \mathrm{C}$ followed by overnight at $4^{\circ} \mathrm{C}$. Six hundred microlitres of phosphate buffered saline, pH 7.35, were added and the gamma globulin aggregate was removed by centrifugation. The supernatant was then analysed in the rubella IgM RIA and the RF RIA.

STATISTICAL METHODS

The discriminant functions in Figs 1 and 2 were calculated by multivariate analysis, according to $\frac{D}{O}$ Armitage (1971).

\section{Results}

ACTIVATION OF RHEUMATOID FACTOR DURING ACUTE RUBELLA INFECTIONS

Serial serum specimens from 28 patients with acute rubella infections were tested for RF. In 27 out of $28 \stackrel{\circ}{C}$ cases, the RF content remained stable during the $\mathbb{\mathscr { D }}$ illness and was between 5 and 50 units, with a mean of 10.0 units. One patient showed an increase of RF content from 20 to 65 units during the acute phase of the disease. The maximum RF level of this patient $\cong$ was detected nine days after onset of rash, after $\unrhd$ which the RF level declined to a value of 15 units 58 ס days after onset of rash. 


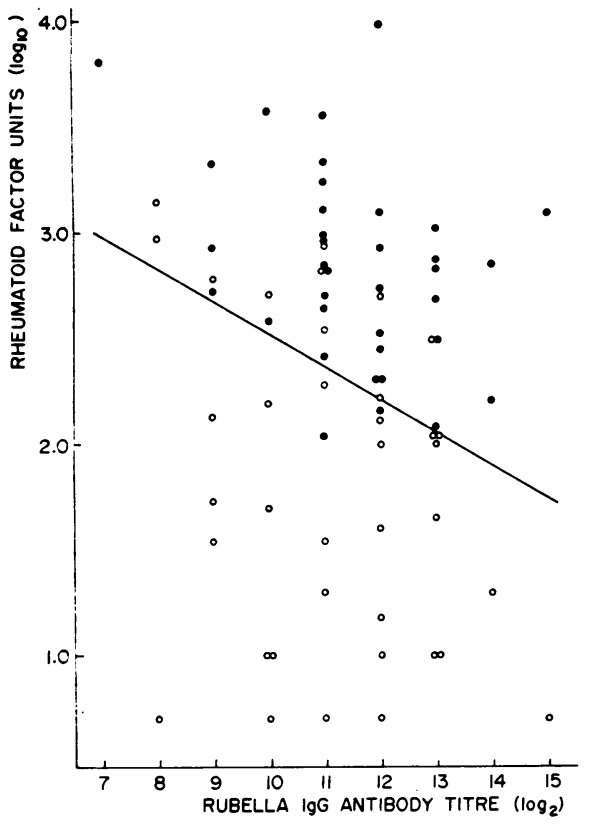

Fig. 1 Occurrence of false-positive rubella IgM antibody results correlated to rheumatoid factor levels and rubella IgG antibody titres of serum specimens from 61 patients with rheumatoid arthritis and 12 other patients without acute rubella infections: $(\mathbf{O})$ serum giving a false-positive rubella IgM antibody result; $(\bigcirc)$ serum giving a negative rubella IgM antibody result. The solid line represents the discriminant function $(z=x+$ $6.51 y, z_{0}=26.4$ ).

FALSE-POSITIVE RUBELLA IgM RIA RESULTS CAUSED BY RF: CORRELATION WITH RF LEVELS AND RUBELLA IgG ANTIBODY TITRES

Serum specimens from 61 patients with RA and from 12 other patients with raised RF levels but not having an acute rubella infection were tested for rubella IgG and IgM antibodies and for RF (Fig. 1). In this series, all patients having RF levels below 100 units were negative and all patients having RF levels over 1500 units were positive in the rubella IgM antibody RIA. The occurrence of false-positive IgM results was also dependent on the rubella IgG antibody titre; when the IgG antibody titre was high, less RF was needed to cause a false-positive IgM result than if the IgG titre was low. The inverse relationship of the RF level and the rubella IgG titre, which are together required to cause a false-positive rubella IgM antibody result, was statistically demonstrated by calculation of a discriminant function (Fig. 1).

In order experimentally to verify the dependence

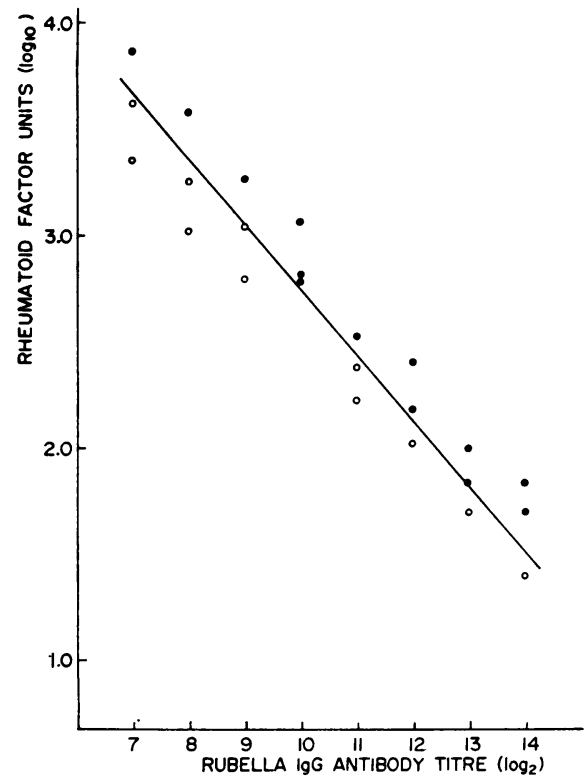

Fig. 2 Occurrence of false-positive rubella IgM antibody results correlated to rheumatoid factor levels and rubella IgG antibody titres. In the experiment, three sera were blended to obtain serum mixtures with different IgG titres and rheumatoid factor levels: (৩) serum giving a false-positive rubella IgM antibody result; $(\bigcirc)$ serum giving a negative rubella IgM antibody result. The solid line represents the discriminant function $\left(z=x+3 \cdot 24 y, z_{0}=18 \cdot 9\right)$.

of a false-positive IgM result on both the RF level and the IgG titre of a serum, additional experiments were undertaken. Three serum specimens, one with a high RF level and a low rubella IgG antibody titre, one with a low RF level and a high rubella antibody titre, and one with a low RF level and no rubella IgG antibodies, were blended in different ratios to obtain mixtures with various IgG titres and RF levels. These were then tested for rubella IgG and IgM antibodies and for RF (Fig. 2). A smaller individual variation was observed and a slightly different discriminant function was obtained; the results, however, fully confirm the conclusions drawn with regard to the data presented in Figure 1.

When the ct/min versus serum dilution curves of sera having false-positive rubella IgM results were plotted, a much sharper decline in slope was observed than in similar curves for sera with true rubella IgM (data not shown). As a result, the false-positive rubella IgM titres caused by RF interference were low; the geomett ic mean titre of the 36 IgM falsepositive specimens presented in Fig. 1 was only 300 . In general, the false-positive IgM titres showed a 
positive correlation to both the rubella IgG titres and the RF levels of the sera. As shown in Table 1, when sera with a rubella IgG titre of 2000 were analysed, the geometric mean titre of false-positive rubella IgM rose from 30 to 250 as the RF levels of the sera increased. Similarly, when sera with RF levels of between 505 and 2000 units were analysed, the geometric mean titre of the false-positive rubella IgM rose from 40 to 2000 as the rubella IgG titres of the sera increased.

Table 1 Correlation of false-positive rubella IgM titres to rheumatoid factor $(R F)$ levels and rubella IgG titres

\begin{tabular}{llllr}
\hline $\begin{array}{l}\text { Sera having rubella IgG titres } \\
\text { of } 2048\end{array}$ & & \multicolumn{2}{l}{$\begin{array}{l}\text { Sera having } \text { RF levels of } \\
\text { 505-2000 units }\end{array}$} \\
\cline { 1 - 2 } \cline { 5 - 6 } RF units & $\begin{array}{l}\text { Rubella IgM } \\
\text { GMT* }\end{array}$ & & $\begin{array}{l}\text { Rubella IgG } \\
\text { titre }\end{array}$ & $\begin{array}{c}\text { Rubella IgM } \\
\text { GMT }\end{array}$ \\
\hline $100-250$ & $30(2) \dagger$ & & 512 & $40(3) \dagger$ \\
$260-500$ & $70(4)$ & & 2048 & $190(7)$ \\
$505-750$ & $120(3)$ & & 4096 & $400(3)$ \\
$850-1750$ & $250(4)$ & 8000 & $2000(3)$ \\
\hline
\end{tabular}

* Geometric mean titre. †Number of specimens.

REMOVAL OF RF BY ABSORPTION WITH AGGREGATED HUMAN GAMMA GLOBULIN Results of RF and rubella IgM antibody determinations of serum specimens from 12 representative patients before and after absorption of RF are shown in Table 2. RF was absorbed effectively from most of the serum specimens by a single absorption step; only specimens with a very high RF content required a second absorption. True rubella IgM titres were not affected by the absorption procedure, whereas fasle-positive IgM titres were effectively eliminated by the removal of RF.

Table 2 Rheumatoid factor $(R F)$ levels and rubella IgM antibody titres in 12 serum specimens before and after removal of rheumatoid factor

\begin{tabular}{|c|c|c|c|c|c|}
\hline \multirow[t]{2}{*}{ Patient } & \multirow[t]{2}{*}{ Diagnosis } & \multicolumn{2}{|l|}{$R F$ units } & \multicolumn{2}{|c|}{ Rubella IgM titre } \\
\hline & & $\begin{array}{l}\text { Before } \\
\text { absorption }\end{array}$ & $\begin{array}{l}\text { After } \\
\text { absorption }\end{array}$ & $\begin{array}{l}\text { Before } \\
\text { absorption }\end{array}$ & $\begin{array}{l}\text { After } \\
\text { absorption }\end{array}$ \\
\hline $\begin{array}{l}\text { HV } \\
\text { AR } \\
\text { PI } \\
\text { MH } \\
\text { EA } \\
\text { LI } \\
\text { JP } \\
\text { LV } \\
\text { LS } \\
\text { LE } \\
\text { TP } \\
\text { ÄA }\end{array}$ & $\begin{array}{l}\text { Control } \\
\text { Rubella } \\
\text { Rubella } \\
\text { Rubella } \\
\text { RA* } \\
\text { RA } \\
\text { RA } \\
\text { RA } \\
\text { RA } \\
\text { RA } \\
\text { RA } \\
\text { RA }\end{array}$ & $\begin{array}{r}10 \\
10 \\
10 \\
20 \\
110 \\
480 \\
850 \\
970 \\
1250 \\
1250 \\
3600 \\
9500\end{array}$ & $\begin{array}{r}5 \\
5 \\
5 \\
10 \\
5 \\
10 \\
10 \\
10 \\
5 \\
5 \\
30 \\
395 \\
30 \dagger\end{array}$ & $\begin{array}{r}<16 \\
2048 \\
8000 \\
16000 \\
128 \\
256 \\
256 \\
256 \\
4096 \\
8000 \\
4096 \\
1024\end{array}$ & $\begin{array}{r}<16 \\
2048 \\
8000 \\
16000 \\
<16 \\
<16 \\
<16 \\
<16 \\
<16 \\
<16 \\
<16 \\
1024 \\
<16 \dagger\end{array}$ \\
\hline
\end{tabular}

*Rheumatoid arthritis. †After a second absorption.

\section{Discussion}

Transient RF activation has been reported in con- $\Rightarrow$ nection with the acute phase of several viral infec-? tions (Dresner and Trombly, 1959; Svec and Dingle,, 1965; Wager et al., 1968; Knez et al., 1976). Activation of RF has been reported to occur occasionally in normal rubella infection (Johnson and Hall, 1958) and more frequently in rubellaw infection complicated by arthritis (Johnson and Hall $\overrightarrow{0}$ 1958; Lee et al., 1960). Kantor and Tanner (1962), however, could not detect RF activation in rubellace infections with arthritic complications. If RF activa tion does occur during viral infections and if it is strong enough to cause a false-positive IgM result, it $\underline{\omega}$ can in some cases interfere with distinguishing ${ }^{\circ}$ between a primary and a secondary infection. More- $-\infty$ over, in primary viral infections, if the RF activation ${ }_{0}^{\omega}$ lasts longer than the true IgM antibody response, it ${ }^{P}$ may lead to a mistake in the timing of the onset of the $\overrightarrow{\vec{z}}$ infection. In the present study, transient RF activa-0 tion was noticed in only one out of 28 acute rubella patients, and in this case the RF level produced was not high enough to interfere with the RIA detection ${ }^{\infty}$ of true rubella IgM antibodies.

A more serious source of error for IgM antibodys tests are patients with rheumatoid arthritis ando related disorders in whom continuously high levels ofôn circulating RF are often present. As has been $\mathbb{R}$ demonstrated for the IFAT (Shirodaria et al., 1973), the present RIA test for IgM antibodies is sensitive to interference by RF. If the IgG titre of a serum waslow, a high RF level was needed to cause a false:0 positive IgM result; on the other hand, with a high IgG antibody titre, only a relatively low RF level was required for interference. It is important to recognise this when studying virus-specific IgM in patients in whom exceptionally high IgG titres are concurrently present to the same virus. Examples are patients with progressive rubella panencephalitis (Weil et al., 1975) and patients with subacute sclerosing panen $\frac{7}{0}$ cephalitis caused by measles (Connolly et al., 1967)

False-positive IgM results caused by the presence of RF can be avoided by absorption of the RF from specimens with heat-aggregated human gamma globulin (Shirodaria et al., 1973). This procedure was ${ }^{\omega}$ effective in our hands, and a significant level of RF was seldom left in a serum specimen after one absorption step. This agrees with the results ofe Shirodaria et al. (1973) but disagrees with those of Gispen et al. (1975), who found aggregated gamma globulin absorption to be ineffective in removing $R F_{\bar{D}}$ from sera with high RF levels.

The results of the present study indicate that, when IgM antibodies are measured by RIA, the possibility of a false-positive result caused by the presence of RFO 
must be recognised and checked for if necessary. Since the increasingly used enzyme-linked immunosorbent assay is based on principles analogous to those of the present RIA methodology, similar precautions against false-positive results are necessary for any enzyme-based IgM antibody test. Measurement of RF levels must be done with a method of sensitivity equal to that of the test used for measurement of the IgM antibodies, since in sera with high IgG titres even low RF levels, not demonstrable by conventional RF tests, can cause a false-positive IgM antibody result. RF interference can, however, be easily and effectively overcome through removal of the RF by absorption with aggregated gamma globulin without affecting true IgM antibody titres.

The excellent technical assistance of Miss Kaija Johansson is gratefully acknowledged.

This study was supported by a grant from the Research and Science Foundation of Lääke Oy, and the Emil and Blida Maunula Foundation. BRZ is the recipient of a Centennial Fellowship from the Medical Research Council of Canada.

\section{References}

Armitage, P. (1971). Stastical Methods in Medical Research, pp. 332-340. Blackwell, Oxford and London.

Connolly, J. H., Allen, I. V., Hurwitz, L. J., and Millar, J. H. D. (1967). Measles-virus antibody and antigen in subacute sclerosing panencephalitis. Lancet, 1, 542-544.

Dresner, E., and Trombly, P. (1959). The latex-fixation reaction in non-rheumatic diseases. New England Journal of Medicine, 261, 981-988.

Gerna, G., and Chambers, R. W. (1976). Rubella antibody assay by the immunoperoxidase technique: comparison with the hemagglutination inhibition test for determination of immune status. Journal of Infectious Diseases, 133, 469-472.

Gispen, R., Nagel, J., Brand-Saathof, B., and DeGraaf, S. (1975). Immunofluorescence test for IgM rubella antibodies in whole serum after absorption with anti$\gamma$ Fc. Clinical and Experimental Immunology, 22, 431437.

Haire, M., and Hadden, D. S. M. (1970). Immunoglobulin responses in rubella and its complications. British Medical Journal, 3, 130-132.

Johnson, R. E., and Hall, A. P. (1958). Rubella arthritis. Report of cases studied by latex tests. New England Journal of Medicine, 258, 743-745.

Kalimo, K. O. K., Meurman, O. H., Halonen, P. E., Ziola, B. R., Viljanen, M. K, Granfors, K., and Toivanen, P. (1976). Solid-phase radioimmunoassay of rubella virus immunoglobulin $\mathrm{G}$ and immunoglobulin $\mathrm{M}$ antibodies. Journal of Clinical Microbiolog)', 4, 117123.

Kantor, T. G., and Tanner, M. (1962). Rubella arthritis and rheumatoid arthritis. Arthritis and Rheumatism, 5, 378-383.

Knez, V., Stewart, J. A., and Ziegler, D. W. (1976). Cytomegalovirus specific IgM and IgG response in humans studied by radioimmunoassay. Journal of Immunology, 117, 2006-2013.

Lee, P. R., Barnett, A. F., Scholer, J. F., Bryner, S., and Clark, W. H. (1960). Rubella arthritis. A study of 20 cases. California Medicine, 93, 125-128.

Liebhaber, H., Pajot, T., and Riordan, J. T. (1969). Growth of high titered rubella virus in roller bottle cultures of Vero cells. Proceedings of the Society of Experimental Biology and Medicine, 130, 12-14.

Meurman, O. H., Viljanen, M. K., and Granfors, K. (1977). Solid-phase radioimmunoassay of rubella virus immunoglobulin $\mathbf{M}$ antibodies: Comparison with sucrose density gradient centrifugation test. Journal of Clinical Microbiology, 5, 257-262.

Shirodaria, P. V., Fraser, K. B., and Stanford, F. (1973). Secondary fluorescent staining of virus antigens by rheumatoid factor and fluorescein conjugated antiIgM. Annals of the Rheumatic Diseases, 32, 53-57.

Svec, K. H., and Dingle, J. H. (1965). The occurrence of rheumatoid factor in association with antibody response to influenza A2 (Asian) virus. Arthritis and Rheumatism, 8, 524-529.

Voller, A., and Bidwell, D. E. (1975). A simple method for detecting antibodies to rubella. British Journal of Experimental Pathology, 56, 338-339.

Wager, O., Räsänen, J. A., Hagman, A., and Klemola, E. (1968). Mixed cryoimmunoglobulinaemia in infectious mononucleosis and cytomegalovirus mononucleosis. International Archives of Allergy and Applied Immunology, 34, 345-361.

Weil, M. L., Itabashi, H. H., Cremer, N. E., Oshiro, L. S., Lennette, E. H., and Carnay, L. (1975). Chronic progressive panencephalitis due to rubella virus simulating subacute sclerosing panencephalitis. New England Journal of Medicine, 292, 994-998.

Ziola, B. R., Matikainen, M.-T., and Salmi, A. A. (1977). Polystyrene balls as the solid-phase of a double antibody radioimmunoassay for human serum albumin. Journal of Immunological Methods, 17, 309-317.

Ziola, B. R., Meurman, O. H., Salmi, A. A., Matikainen, M.-T., and Kalliomäki, J. L. (1978). Determination of human IgM-class rheumatoid factor by a solid-phase radioimmunoassay employing human IgG in antigenantibody complexes. (Submitted for publication).

Requests for reprints to: Dr O. Meurman, Department of Virology, University of Turku, Kiinamyllynkatu 10, SF-20520 Turku, Finland. 